\title{
Flaming to control weeds in seashore paspalum (Paspalum vaginatum Sw.) turfgrass
}

\author{
Luisa Martelloni, Marco Fontanelli, Lisa Caturegli, Monica Gaetani, Nicola Grossi, Simone Magni, \\ Andrea Peruzzi, Michel Pirchio, Michele Raffaelli, Marco Volterrani, Christian Frasconi \\ Department of Agriculture, Food and Environment, University of Pisa, Italy
}

\begin{abstract}
Weed control is crucial to ensure that turfgrass is established effectively. Although herbicides are commonly used to control weeds in turfgrasses, environmental and public health concerns have led to limiting or banning the use of synthetic herbicides in urban areas. The species seashore paspalum (Paspalum vaginatum Sw.) is susceptible to such herbicides. Flame weeding could be an alternative to the use of synthetic herbicides for selective weed control in seashore paspalum. In this study, five different liquefied petroleum gas (LPG) doses of flaming $(0,61,91,157$ and $237 \mathrm{~kg}$ $\mathrm{ha}^{-1}$ ) were tested in order to find the optimal dose, in terms of weed control and costs. The aim was to maintain a seashore paspalum (cultivar 'Salam') turf free of weeds during spring greenup, and at the same time avoid damaging the turfgrass. Using a self-propelled machine designed and built at the University of Pisa, flaming was applied three times when weeds started growing and the turfgrass started green-up. Our results highlight that an LPG dose of $157 \mathrm{~kg} \mathrm{ha}^{-1}$ was the most economic dose that led to a significant reduction in initial weed cover and density, enabling the turfgrass to recover three weeks after the third application.
\end{abstract}

Correspondence: Luisa Martelloni, Department of Agriculture, Food and Environment, University of Pisa, via del Borghetto 80, 54124 Pisa, Italy.

Tel.: +39.050.2218966.

E-mail: 1martelloni@agr.unipi.it

Key words: Flame weeding; green-up; non-chemical; thermal methods; turfgrass management; warm-season.

Funding: this study was part of the Tecnologie innovative per una gestione efficiente ed eco-compatibile dei tappeti erbosi project, funded by the University of Pisa (Progetti di Ricerca di Ateneo, 2016).

Conflict of interests: the authors declare no potential conflict of interests.

Received for publication: 6 September 2018 .

Accepted for publication: 19 June 2019.

${ }^{\circ}$ Copyright: the Author(s), 2019

Licensee PAGEPress, Italy

Journal of Agricultural Engineering 2019; L:904

doi:10.4081/jae.2019.904

This article is distributed under the terms of the Creative Commons Attribution Noncommercial License (by-nc 4.0) which permits any noncommercial use, distribution, and reproduction in any medium, provided the original author(s) and source are credited.

\section{Introduction}

Pressure is increasing on the turfgrass industry to reduce maintenance inputs (Brede, 2000). Turfgrass scientists and managers have thus been investigating turfgrass management systems that require lower inputs (Żurek and Tomaszewski, 2009). One of the most important traits for a low-input sustainable turf is the ability of the turfgrass to cover the ground. A good coverage reduces dust, mud, and weed problems (Diesburg et al., 1997).

Weed control is crucial in order to ensure that turfgrass establishes in an optimal way (Abu-Dieyeh and Watson, 2005). Herbicides are commonly used to control weeds but environmental and public health concerns have led to legislation that limits or bans the use of synthetic herbicides in urban areas (Cisar, 2004; European Commission, 2009; Robbins and Birkenholtz, 2003). Few effective natural options for weed control in turfgrass are currently available, and bioherbicides derived from fungi do not offer a comparable effective broad-spectrum weed control to common synthetic herbicides (Smith et al., 2015). Cultural management practices to control weeds in turfgrass may reduce the dependence on synthetic herbicides. Busey (2003) used mowing to control turfgrass weeds and this provoked changes in population abundance and diversity of weeds, thereby creating new competitive species against turfgrass.

Turfgrasses that do not require frequent artificial irrigations are less likely to be invaded by weeds (Żurek and Tomaszewski, 2009). Seashore paspalum (Paspalum vaginatum Sw.) is a warmseason turfgrass known for its tolerance to drought (Trenholm et $a l ., 2000)$. Seashore paspalum is commonly planted in tropical and warm temperature regions for golf courses, sports fields, and lawns (Duncan and Carrow, 2000). A major limitation of seashore paspalum weed management is the susceptibility to chemical herbicide injury when applied during active growth (Reed and McCullough, 2014; Yu et al., 2015). Turf managers apply herbicides in late winter or after the green-up (Reed and McCullough, 2014), however this is when weeds may already have colonised the turfgrass. Furthermore, seashore paspalum have been found to have poor spring green-up compared with other warm-season turfgrasses (Croce et al., 2001).

Flame weeding could be an alternative to the use of chemical herbicides in seashore paspalum. In laboratory conditions, Fontanelli et al. (2017) tested the effects of flaming on seedlings of seashore paspalum transplanted into trays. They found that the seedlings were tolerant to liquefied petroleum gas (LPG) doses of about $40 \mathrm{~kg} \mathrm{ha}^{-1}$, which suggests that in mature established turfgrasses, which have a network of reserve rhizomes and stolons underground (Gaetani et al., 2017), the doses tolerated are likely to be higher.

To the best of our knowledge, no information is available on the effects of flaming for controlling weeds in a mature turfgrass of seashore paspalum (Paspalum vaginatum $\mathrm{Sw}$.). The aim of this 
study was to test different LPG flaming doses in order to find the optimal dose, in terms of weed control and costs, that would keep a 'Salam' seashore paspalum turf free of weeds during the spring green-up, and at the same time avoid damaging the turfgrass.

\section{Materials and methods}

\section{Flaming machine}

Flaming was conducted using a self-propelled machine designed and built at the University of Pisa. This machine had been previously used for weed control in urban contexts (Raffaelli et al., 2013). The machine was equipped with four wheels (with two front drive wheels) and a $4.4 \mathrm{~kW}$ four-stroke gasoline engine, and was driven by a walking operator. The forward speed can be increased from 1 up to $5 \mathrm{~km} \mathrm{~h}^{-1}$. The machine was equipped with five $25 \mathrm{~cm}$ wide rod burners with an external nozzle (diameter 1.1 $\mathrm{mm}$ ) (Raffaelli et al., 2015) placed in front of a small frame, with a working width of $125 \mathrm{~cm}$. All the burners can be adjusted by varying height and inclination with respect to the soil surface. In this experiment the burners were set at a height of $7 \mathrm{~cm}$ at an angle of $45^{\circ}$ to the ground (Figure 1). The machine was equipped with a heat exchange system. Two LPG tanks are placed inside a hopper that contains water. The water is heated by the exhaust gas, which passes through a copper tube inside the hopper.

The LPG doses used during the experiment were 61, 91, 157, and $237 \mathrm{~kg} \mathrm{ha}^{-1}$. These LPG doses were based on weed species and stage of development observed at the beginning of the experiment, and on previous experience in the selection of LPG doses for controlling weeds (Martelloni et al., 2016; Frasconi et al., 2017; Martelloni et al., 2017; Peruzzi et al., 2017). These doses were obtained by maintaining the LPG pressure constant at $0.35 \mathrm{MPa}$ and by varying the forward speed.

\section{Experimental set-up, design and treatments}

The experiment was conducted in spring 2016 at the experimental farm of the Department of Agriculture, Food and Environment of the University of Pisa (San Piero a Grado, Pisa,
Italy) $\left(43^{\circ} 40^{\prime} \mathrm{N}, 10^{\circ} 19^{\prime} \mathrm{E}, 6 \mathrm{~m}\right.$ a.s.1.) on a mature warm-season turfgrass stand of seashore paspalum (Paspalum vaginatum Sw.) variety 'Salam'. The turfgrass was established on a calcaric fluvisoil (coarse-silty, mixed, thermic, typic xerofluvents), with a $\mathrm{pH}$ of 7.8 and $2.2 \%$ of organic matter.

Fertilisation of the turfgrass consisted in the application of 100 $\mathrm{kg} \mathrm{ha} \mathrm{a}^{-1}$ of $\mathrm{N}$ in March 2016 using a centrifugal spreader. Ammonium sulphate (21-0-0) was used as the N source. The turfgrass was not irrigated and mowed during the experiment in order to observe only the effect of different LPG doses of flaming.

At the start of the experiment (11 April), the weeds identified in the turfgrass were Anagallis arvensis L., Aster squamatus (Spreng.) Hieron, Bellis perennis L., Conyza albida Spreng., Convolvulus arvensis L., Picris hieracioides L., Poa annua L., Sonchus arvensis L., Trifolium repens L., Veronica persica (Poir.). All dicotyledons were from the cotyledonary to four-leaf growth stage. Poa annua L. was at an early seedling stage. The most abundant weeds were Aster squamatus (Spreng.) Hieron, Picris hieracioides L., and Poa annua L.. Weed composition was homogeneous among plots at the beginning of the study.

Flaming was conducted three times, on April $11^{\text {th }}$, April $28^{\text {th }}$ and May $10^{\text {th }}$, within a period during which weeds were competitive and the turfgrass started the green-up. The maximum, minimum and average temperatures, and cumulative rainfall are reported in Figure 2.

The experimental design was a randomised block design with three blocks. Treatments consisted in the application of four different LPG doses $\left(61,91,157\right.$, and $\left.237 \mathrm{~kg} \mathrm{ha}^{-1}\right)$ and a weedy control plot (no flaming application) for each plot, for a total of 15 plots. Plot size was $4 \times 1.25 \mathrm{~m}\left(5 \mathrm{~m}^{2}\right)$.

\section{Data collection}

Machine performance was calculated. The field efficiency of the machine (i.e. the ratio of the theoretical field time and the total time spent in the field) was computed by using an ideal area of $1000 \mathrm{~m}^{2}$ (10 $\mathrm{m}$ wide and $100 \mathrm{~m}$ long). The total operating time of the machine was calculated by summing the machine preparation time in the field before and after operation, the theoretical field time, the turning time, and the time to refuel the machine and replace empty LPG tanks. The machine preparation time at the

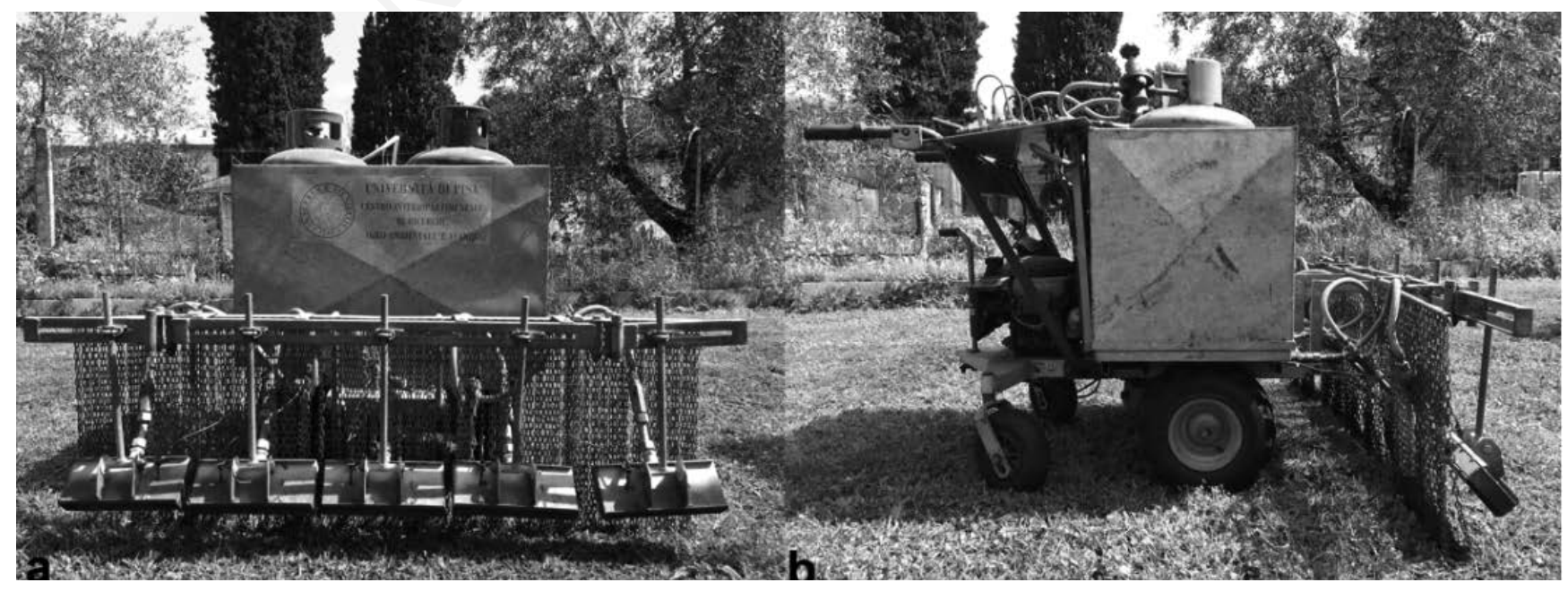

Figure 1. The self-propelled flaming machine: A) front view; B) side view. 
establishment and the travel time to and from the field were not included. The total cost per use was calculated by summing fixed and variable costs for each LPG dose used, following a standard methodology for cost determination (Hunt, 2001). The rate of depreciation was determined considering a purchase price of 5100 $€$. The economic lifetime was 8 years, the factor for repair and maintenance was $75 \%$. The labour cost for the operator was $16.8 €$ $\mathrm{h}^{-1}$, and the LPG cost $2.27 € \mathrm{~kg}^{-1}$.

Data regarding weed cover and density were collected before the first flaming (the same day) and after each of the three flaming treatments. The assessments on weeds carried out after flaming occurred in the same days in which turfgrass green-up was estimated: 14 days after the first flaming (maximum potential recovery time between the first and the second flaming), 7 days after the second flaming (mid time between the second and the third flaming), and 21 days after the third flaming (when some of the plots first had reached the $90 \%$ green-up threshold).

Weed cover data were collected by using a custom-built reference grid, consisting of a $30 \times 30 \mathrm{~cm}$ frame containing one hundred $3 \times 3 \mathrm{~cm}$ squares. Each square covered by weeds corresponded to $1 \%$ weed cover. For each plot, the weed cover was collected twice. Weed density data were collected by counting weeds within a $30 \times 30 \mathrm{~cm}$ frame. For each plot the count was replicated twice. During the counts the weed plants were identified and separated by species, but only the total number of weed plants was analysed. Weed density was reported as plants $\mathrm{m}^{-2}$. Data regarding weed cover and density were always collected in the same area within the plot. Green-up was evaluated by visual rating in terms of the percentage of green turfgrass coverage on the total area of each experimental unit. A rating scale of $0 \%$ (no turfgrass coverage) to $100 \%$ (total experimental unit covered by the turfgrass) was used.

\section{Statistical analysis}

Data normality was tested using the Shapiro-Wilk test. Other tests consisted of Student's $t$-test to verify that the mean of the errors was not significantly different from zero, the Breusch-Pagan for homoscedasticity, and the Durbin-Watson test for serial correlation.

The weed density data followed a Poisson distribution (count data), and were modelled in a generalized linear mixed model in $\mathrm{R}$ software (R Core Team, 2016) assessing the Poisson distribution by using the $\mathrm{R}$ extension package lme4 (Fitting Linear MixedEffects Models Using lme4) (Bates et al., 2015). LPG doses and the day of data collection were the fixed factors. The random factor was " $1+$ day of data collection|blocks:replicates" to allow the slope of the day of data collection variable to vary by replicates within blocks. The model ran a log transformation. The weed cover and turfgrass green-up data were modelled in a linear mixed model, setting a logit transformation in $\mathrm{R}$ software, using the extension package 'ImerTest' (Tests in Linear Mixed Effects Models) (Kuznetsova et al., 2016). LPG doses and the day of data collection were the fixed factors. The random factor of weed cover was the same of weed density. The random factor of the turfgrass green-up was "1+ day of data collection|blocks" to allow the slope of the day of data collection variable to vary by blocks. An analysis of variance was run for each model.

The extension package 'effects' (Effect Displays for Linear, Generalised Linear, and Other Models) (Fox, 2003) was used to estimate the mean values and standard errors (and inverse transformations) of the dependent variables obtained from the models at the different LPG doses used and at the different days of data collection. The pairwise comparisons between mean values were computed by estimating the $95 \%$ confidence interval of the differ- ence between the values (Eq. 1).

$$
\mathrm{CI}(\text { difference })=\left(\mathrm{x}_{1}-\mathrm{x}_{2}\right) \pm 1.96 \sqrt{\left(\mathrm{SE}_{\mathrm{X}_{1}}\right)^{2}+\left(\mathrm{SE}_{\mathrm{X}_{2}}\right)^{2}}
$$

where $\left(\mathrm{x}_{1}\right)$ is the mean of the first value, $\left(\mathrm{x}_{2}\right)$ is the mean of the second value, $\left(\mathrm{SEx}_{1}\right)$ is the standard error of $\left(\mathrm{x}_{1}\right)$, and $\left(\mathrm{SEx}_{2}\right)$ is the standard error of ( $\left.\mathrm{x}_{2}\right)$ (Knezevic, 2008). If the resulting 95\% confidence interval (CI) of the difference between values did not cross the value 0 , the null hypothesis that the compared values were similar was rejected. The extension package 'ggplot2' (Elegant Graphics for Data Analysis) (Wickham, 2009) was used to plot graphs.

\section{Results}

\section{Machine performance and costs}

Machine performance and costs are reported in Table 1. Because the LPG doses were obtained by changing the forward speed and maintaining the working pressure $(0.35 \mathrm{MPa})$ constant, the effective field capacity decreased by increasing the LPG dose. Consequently, the costs increased by increasing the LPG dose.

\section{Weed cover}

Analysis of variance of the weed cover model showed that there was a statistically significant effect of the dose, of the day of data collection and their interaction $(\mathrm{P}<0.001)$. The significance of the interaction suggested that different doses did not maintain the same weeding effect with the passage of time. The repeated application of higher doses led to lower weed coverage with the passage of time compared to lower doses (Figure 3). Regression lines are

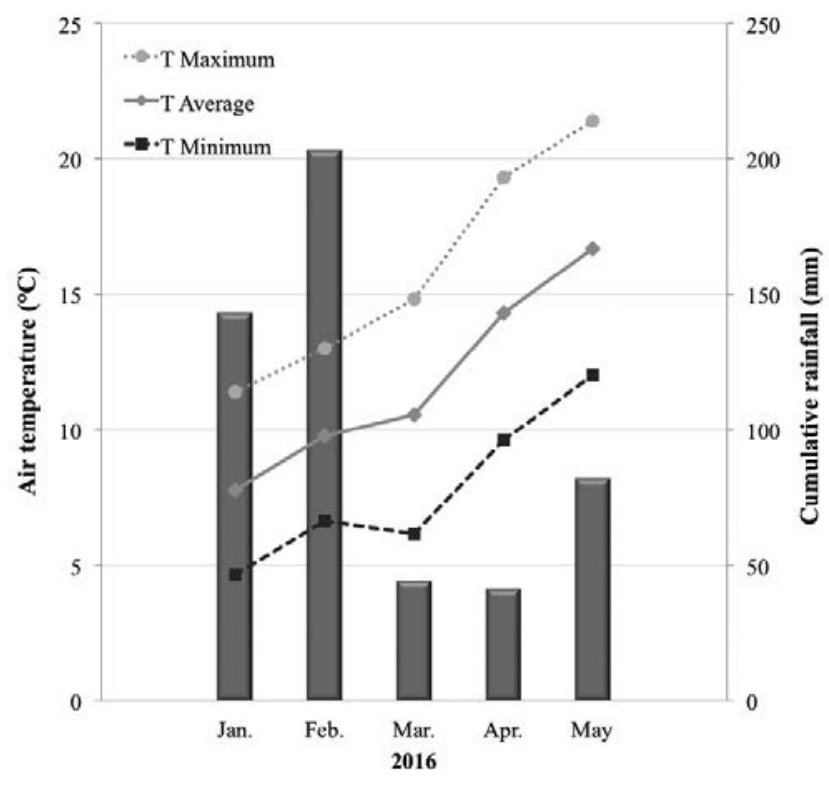

Figure 2. Monthly (January to May 2016) cumulated rainfall, and monthly average, maximum, and minimum temperatures recorded by the meteorological station at San Piero a Grado (Pisa, Italy). 
shown in Figure 3. Table 2 shows the means and standard errors of the weed cover logit transformed (and inverse transformed values) estimated from the model as a function of the different LPG doses used and at the four days of data collection.

Before flaming, weed cover was statistically similar and relatively high in all plots (from $16 \%$ to $38 \%$ ). Two weeks after the first flaming, the weed cover values remained statistically similar to before the treatment, at all the LPG doses used. When the LPG doses of 157 and $237 \mathrm{~kg} \mathrm{ha}^{-1}$ were used, significantly lower values of weed cover, compared to before flaming, were found one week after the second treatment (Figure 3, Table 2). At the same time, the LPG doses of 61 and $91 \mathrm{~kg} \mathrm{ha}^{-1}$ did not significantly reduce the weed cover. Compared with weed cover before the start of the experiment, three weeks after the third flaming weed cover decreased significantly at all LPG doses. This decrease was higher when the LPG dose of $237 \mathrm{~kg} \mathrm{ha}^{-1}$ was used; after the third flaming, the percentage of weed cover was significantly smaller than at the other doses. The LPG dose of $157 \mathrm{~kg} \mathrm{ha}^{-1}$ led to a higher weed cover percentage than the dose of $237 \mathrm{~kg} \mathrm{ha}^{-1}$, but smaller than the doses of 91 and $61 \mathrm{~kg} \mathrm{ha}^{-1}$, which had statistically similar weed covers to each other.

\section{Weed density}

Analysis of deviance (type II Wald chi-square tests) of the weed density model showed that there was a statistically signifi- cant effect of the dose, of the day of data collection and their interaction $(\mathrm{P}<0.001)$. The significance of the interaction suggested that different doses did not maintain the same number of weeds with the passage of time. The repeated application of higher doses led to a lower number of weeds with the passage of time compared to lower doses (Figure 4). Regression lines are shown in Figure 4. Table 3 reports the means and standard errors of the weed density log transformed (and inverse transformed values) estimated from the model as a function of the different LPG doses used and at the four days of data collection.

The effect of flaming on weed density was observable three weeks after the third application. When the LPG doses of 91, 157 and $237 \mathrm{~kg} \mathrm{ha}^{-1}$ were used, weed density decreased significantly when comparing estimations before the beginning of the experiment and three weeks after the third flaming. The highest decrease was estimated when the LPG dose of $237 \mathrm{~kg} \mathrm{ha}^{-1}$ was used (average decrease of 379 plants $\mathrm{m}^{-2}$ ). After three flaming treatments, the lowest LPG dose used (i.e. $61 \mathrm{~kg} \mathrm{ha}^{-1}$ ) maintained the weed density at the same level as before the beginning of the experiment. Three weeks after the third flaming, weed density in the control was statistically significantly higher compared to before the beginning of the experiment. An average increase of 268 weed plants $\mathrm{m}^{-2}$ was estimated. Weeds at the end of the experiment (31 May) were of the same species of that identified at the start of the experiment.

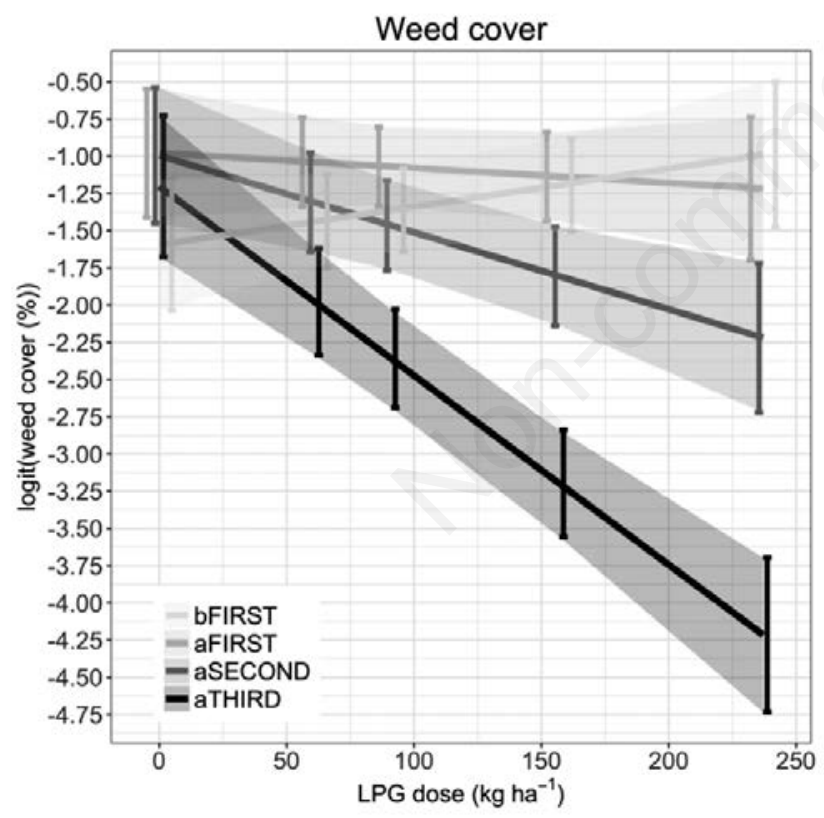

Figure 3. Effect plot of weed cover (logit transformed) and $95 \%$ confidence intervals estimated as a function of the LPG doses used $\left(0,61,91,157\right.$ and $\left.237 \mathrm{~kg} \mathrm{ha}^{-1}\right)$ at the four days of data collection. bFIRST: weed cover before the first flaming (the same day); aFIRST: 14 days after the first flaming; aSECOND: 7 days after the second flaming; aTHIRD: 21 days after the third flaming. AIC value: 301.6 , BIC value: 354 .5. If the confidence intervals do not overlap, then the weed cover values are statistically significantly different. However, the converse is not true, when confidence intervals overlap, the statistical significance has to be calculated (Knezevic, 2008).

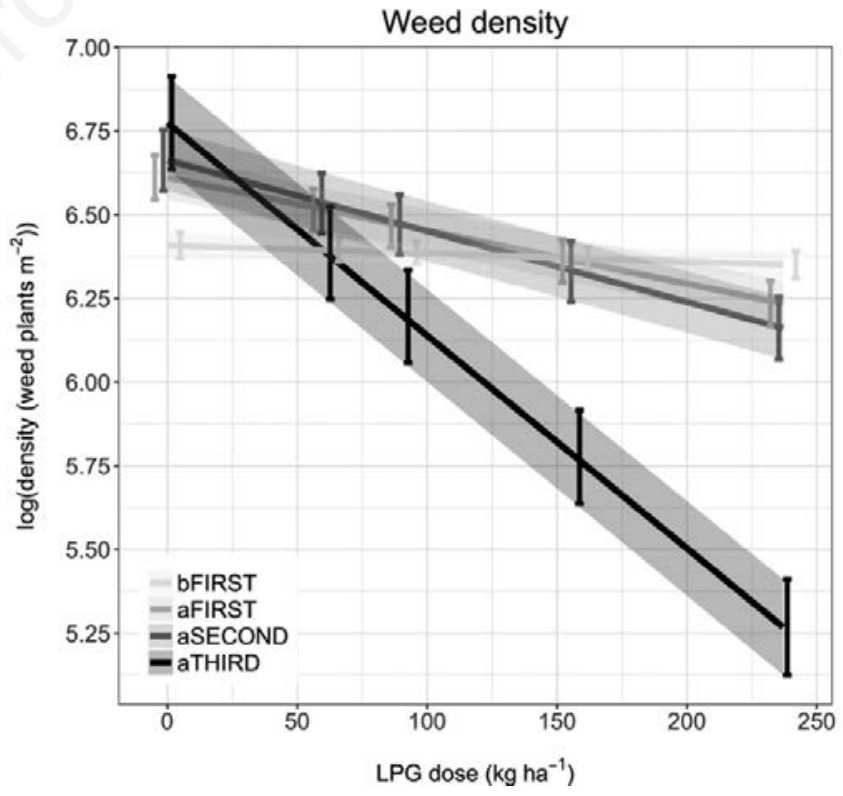

Figure 4. Effect plot of weed density (log transformed following the Poisson distribution) and $95 \%$ confidence intervals estimated as a function of the LPG doses used $\left(0,61,91,157\right.$ and $\left.237 \mathrm{~kg} \mathrm{ha}^{-1}\right)$ at the four days of data collection. bFIRST: weed cover before the first flaming (the same day); aFIRST: 14 days after the first flaming; aSECOND: 7 days after the second flaming; aTHIRD: 21 days after the third flaming. AIC value: 5829.4, BIC value: 5879.6. If the confidence intervals do not overlap, then the weed density values are statistically significantly different. However, the converse is not true, when confidence intervals overlap, the statistical significance has to be calculated (Knezevic, 2008). 


\section{Turfgrass green-up}

Analysis of variance of the turfgrass green-up model showed that there was a statistically significant effect of the dose, of the day of data collection and their interaction $(\mathrm{P}<0.001)$. The significance of the interaction suggested that different doses did not lead to the same level of green-up with the passage of time (Figure 5). Regression lines are shown in Figure 5. Table 4 reports the means and standard errors of the turfgrass green-up logit transformed (and inverse transformed values) estimated from the model as a function of the different LPG doses used and at the four days of data collection.

The turfgrass green-up in the control was statistically similar two weeks after the start of the experiment (25 April) to the end of the experiment (31 May). Three weeks after the third flaming, the

Table 1. Machine performance and cost estimation.

\begin{tabular}{|c|c|c|c|c|}
\hline \multirow[b]{2}{*}{ Performance } & \multicolumn{4}{|c|}{ LPG dose $\left(\mathrm{kg} \mathrm{ha}^{-1}\right)$} \\
\hline & 61 & 91 & 157 & 237 \\
\hline Forward speed $\left(\mathrm{km} \mathrm{h}^{-1}\right)$ & 2.87 & 1.93 & 1.12 & 0.74 \\
\hline Theoretical field capacity $\left(\mathrm{ha}^{-1}\right.$ ) & 0.36 & 0.24 & 0.14 & 0.09 \\
\hline Machine preparation time in the field before and after operation (h) & 0.08 & 0.08 & 0.08 & 0.08 \\
\hline Theoretical field time $(\mathrm{h})^{*}$ & 0.28 & 0.41 & 0.72 & 1.08 \\
\hline Turning time $(\mathrm{h})^{*}$ & 0.03 & 0.03 & 0.03 & 0.03 \\
\hline Time needed to refuel the machine and replace empty LPG tanks (h)* & 0.02 & 0.03 & 0.04 & 0.07 \\
\hline Total time $(\mathrm{h})^{*}$ & 0.41 & 0.55 & 0.87 & 1.26 \\
\hline Field efficiency & 0.68 & 0.75 & 0.82 & 0.86 \\
\hline Effective field capacity $\left(\right.$ ha $\mathrm{h}^{-1}$ ) & 0.24 & 0.18 & 0.11 & 0.08 \\
\hline $\begin{array}{l}\text { Costs } \\
\text { Cost per hour }\left(€ \mathrm{~h}^{-1}\right) \\
\text { Total cost per use }\left(€ \mathrm{~m}^{-2}\right)\end{array}$ & $\begin{array}{c}56.17 \\
0.02\end{array}$ & $\begin{array}{c}59.54 \\
0.03\end{array}$ & $\begin{array}{c}63.06 \\
0.05\end{array}$ & $\begin{array}{c}64.92 \\
0.08\end{array}$ \\
\hline
\end{tabular}

*Time needed for flaming in a area of $1000 \mathrm{~m}^{2}(10 \mathrm{~m}$ wide and $100 \mathrm{~m}$ long).

Table 2. Mean values and standard errors of the weed cover logit transformed estimated from the model as a function of the different liquefied petroleum gas doses used and at the four days of data collection. Inverse transformed means and $95 \%$ confidence intervals are reported.

\begin{tabular}{|c|c|c|c|c|c|}
\hline \multirow[t]{2}{*}{ LPG dose $\left(\mathrm{kg} \mathrm{ha}^{-1}\right)$} & \multirow[t]{2}{*}{ Day of data collection } & \multirow{2}{*}{$\begin{array}{c}\text { logit(weed cover) }(\%) \\
\text { Mean }( \pm \mathrm{SE})\end{array}$} & \multicolumn{3}{|c|}{ Weed cover (\%) (inverse transformed values) } \\
\hline & & & Mean & Lower 95\% CI & Upper $95 \%$ CI \\
\hline 0 & bFIRST & $-1.594(0.222)$ & 16.876 & 19.624 & 23.967 \\
\hline 0 & aFIRST & $-0.979(0.218)$ & 27.316 & 19.008 & 36.648 \\
\hline 0 & aSECOND & $-0.995(0.230)$ & 26.998 & 15.753 & 36.821 \\
\hline 0 & aTHIRD & $-1.202(0.240)$ & 23.109 & 11.564 & 32.573 \\
\hline 61 & bFIRST & $-1.438(0.157)$ & 19.178 & 14.799 & 24.481 \\
\hline 61 & aFIRST & $-1.040(0.151)$ & 26.120 & 20.761 & 32.299 \\
\hline 61 & aSECOND & $-1.310(0.168)$ & 21.251 & 16.213 & 27.344 \\
\hline 61 & aTHIRD & $-1.978(0.181)$ & 12.158 & 8.812 & 16.543 \\
\hline 91 & bFIRST & $-1.362(0.140)$ & 20.396 & 16.248 & 25.283 \\
\hline 91 & aFIRST & $-1.070(0.133)$ & 25.544 & 20.849 & 30.885 \\
\hline 91 & aSECOND & $-1.465(0.152)$ & 18.773 & 14.605 & 23.800 \\
\hline 91 & aTHIRD & $-2.359(0.167)$ & 8.636 & 6.361 & 11.623 \\
\hline 157 & bFIRST & $-1.193(0.157)$ & 23.272 & 18.177 & 29.284 \\
\hline 157 & aFIRST & $-1.136(0.151)$ & 24.308 & 19.233 & 30.220 \\
\hline 157 & aSECOND & $-1.806(0.168)$ & 14.115 & 10.548 & 18.637 \\
\hline 157 & aTHIRD & $-3.198(0.181)$ & 3.924 & 2.774 & 5.524 \\
\hline 237 & bFIRST & $-0.988(0.246)$ & 27.122 & 18.603 & 37.733 \\
\hline 237 & aFIRST & $-1.216(0.242)$ & 22.864 & 15.502 & 32.383 \\
\hline 237 & aSECOND & $-2.219(0.253)$ & 9.805 & 6.180 & 15.212 \\
\hline 237 & aTHIRD & $-4.215(0.262)$ & 1.456 & 0.872 & 2.423 \\
\hline
\end{tabular}

LPG, liquefied petroleum gas; SE, standard error; CI, confidence interval; bFIRST, weed cover before the first flaming (the same day); aFIRST, 14 days after the first flaming; aSECOND, 7 days after the second flaming; aTHIRD, 21 days after the third flaming. 
green-up was statistically similar when all the LPG doses were used. When the LPG doses of 157 and $237 \mathrm{~kg} \mathrm{ha}^{-1}$ were used, the green-up three weeks after the third flaming was statistically higher than the green-up estimated two weeks after the first flaming and one week after the second flaming. When the LPG doses of 61 and $91 \mathrm{~kg} \mathrm{ha}^{-1}$ were used, the green-up estimated three weeks after the third flaming was statistically significantly higher compared with one week after the second flaming, but statistically similar to two weeks after the first flaming.

\section{Discussion}

The self-propelled machine had a higher effective field capacity and lower costs when the two lower LPG doses were used (i.e. 61 and $91 \mathrm{~kg} \mathrm{ha}^{-1}$ ). However, using these doses, the effect of weed control was lower compared with the LPG doses of 157 and 237 $\mathrm{kg} \mathrm{ha}^{-1}$. Both weed cover and density were higher when the lowest LPG doses were used. When the LPG doses of 157 and $237 \mathrm{~kg} \mathrm{ha}^{-1}$ were used, the weed cover was on average $3.9 \%$ and $1.5 \%$, respectively, and was determined by an average of 323 and 194 seedlings per square meter, respectively.

The turfgrass green-up two weeks after the first flaming (26 April) was statistically similar in the control and when all the LPG doses were used. At the same time weed cover was also statistically similar, suggesting that the low green-up (from $53 \%$ to $65 \%$, on average) was probably due to the effect of both weed competition and the slow recovery from dormancy which is a characteristic of seashore paspalum, which is a poor spring green-up warm-season turfgrass (Croce et al., 2001).

One week after the second treatment, the injury caused by

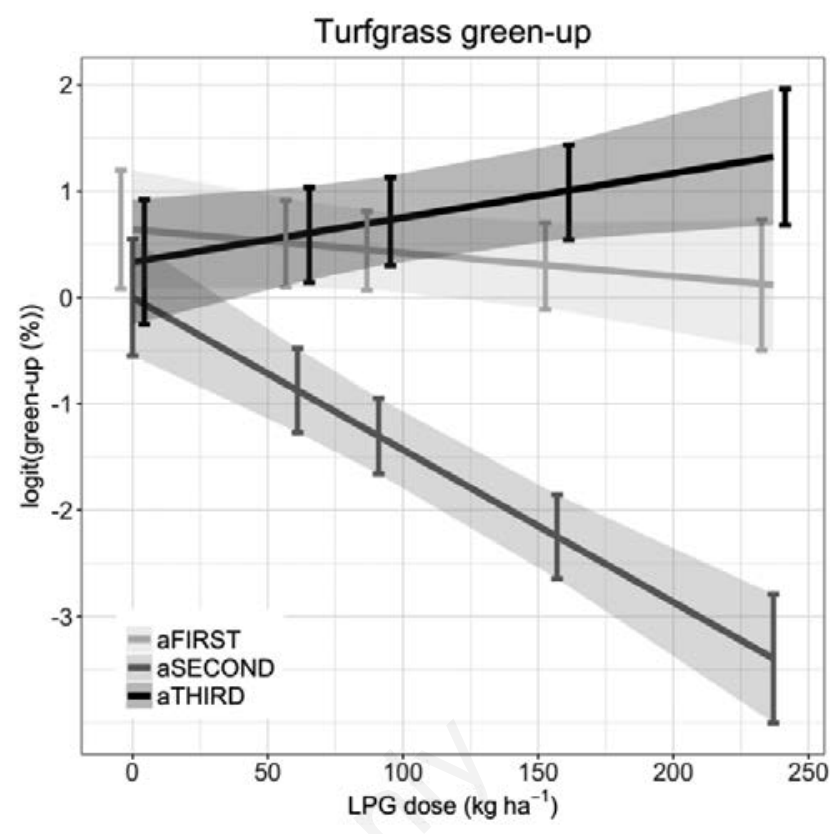

Figure 5. Effect plot of turfgrass green-up (logit transformed) and $\mathbf{9 5 \%}$ confidence intervals estimated as a function of the LPG doses used $\left(0,61,91,157\right.$ and $\left.237 \mathrm{~kg} \mathrm{ha}^{-1}\right)$ at the three days of data collection. aFIRST: 14 days after the first flaming; aSECOND: 7 days after the second flaming; aTHIRD: 21 days after the third flaming. AIC value: 108.3; BIC value: 131.8 . If the confidence intervals do not overlap, then the green-up values are statistically significantly different. However, the converse is not true, when confidence intervals overlap, the statistical significance has to be calculated (Knezevic, 2008).

Table 3. Mean values and standard errors of the weed density log transformed estimated from the model as a function of the different liquefied petroleum gas doses used and at the four days of data collection. Inverse transformed means and $95 \%$ confidence intervals are reported.

\begin{tabular}{|c|c|c|c|c|c|}
\hline LPG dose $\left(\mathrm{kg} \mathrm{ha}^{-1}\right)$ & Day of data collection & log(weed plants $\mathrm{m}^{-2}$ ) & Weed & -2 (inverse tran & rmed values) \\
\hline & & Mean $( \pm S E)$ & Mean & Lower 95\% CI & Upper 95\% CI \\
\hline 0 & bFIRST & $6.408(0.019)$ & 606.795 & 584.404 & 630.0428 \\
\hline 0 & aFIRST & $6.611(0.034)$ & 743.380 & 695.989 & 793.9971 \\
\hline 0 & aSECOND & $6.662(0.047)$ & 782.468 & 714.192 & 857.2712 \\
\hline 0 & aTHIRD & $6.774(0.071)$ & 874.856 & 761.2903 & 1005.363 \\
\hline 61 & bFIRST & $6.393(0.017)$ & 597.868 & 578.3204 & 618.0761 \\
\hline 61 & aFIRST & $6.387(0.033)$ & 674.811 & 633.0928 & 719.2790 \\
\hline 61 & aSECOND & $6.533(0.046)$ & 687.748 & 628.6312 & 752.4239 \\
\hline 61 & aTHIRD & $6.514(0.070)$ & 593.792 & 517.1882 & 681.7417 \\
\hline 91 & bFIRST & $6.386(0.016)$ & 593.526 & 574.6655 & 613.0054 \\
\hline 91 & aFIRST & $6.467(0.032)$ & 643.447 & 603.8756 & 685.6111 \\
\hline 91 & aSECOND & $6.470(0.046)$ & 645.461 & 590.1045 & 706.0102 \\
\hline 91 & aTHIRD & $6.196(0.070)$ & 490.753 & 427.4215 & 563.4675 \\
\hline 157 & bFIRST & $6.370(0.017)$ & 584.084 & 564.9126 & 603.9068 \\
\hline 157 & aFIRST & $6.362(0.033)$ & 579.481 & 543.3930 & 617.9660 \\
\hline 157 & aSECOND & $6.330(0.046)$ & 561.358 & 512.8665 & 614.4333 \\
\hline 157 & aTHIRD & $5.777(0.071)$ & 322.675 & 280.6786 & 370.9545 \\
\hline 237 & bFIRST & $6.351(0.020)$ & 572.841 & 550.4964 & 596.0930 \\
\hline 237 & aFIRST & $6.235(0.035)$ & 510.411 & 476.8139 & 546.3755 \\
\hline 237 & aSECOND & $6.161(0.048)$ & 473.967 & 431.7827 & 520.2726 \\
\hline 237 & aTHIRD & $5.268(0.073)$ & 194.107 & 168.2353 & 223.9567 \\
\hline
\end{tabular}

LPG, liquefied petroleum gas; SE, standard error; CI, confidence interval; bFIRST, weed density before the first flaming (the same day); aFIRST, 14 days after the first flaming; aSECOND, 7 days after the second flaming; aTHIRD, 21 days after the third flaming. 
Table 4. Mean values and standard errors of the turfgrass green-up logit transformed estimated from the model as a function of the different liquefied petroleum gas doses used at the three days of data collection. Inverse transformed means and $95 \%$ confidence intervals are reported.

\begin{tabular}{|c|c|c|c|c|c|}
\hline \multirow[t]{2}{*}{ LPG dose $\left(\mathrm{kg} \mathrm{ha}^{-1}\right)$} & \multirow[t]{2}{*}{$\begin{array}{l}\text { Day of data } \\
\text { collection }\end{array}$} & \multirow{2}{*}{$\begin{array}{c}\text { logit(turfgrass green-up) (\%) } \\
\text { Mean ( }( \pm \mathrm{SE})\end{array}$} & \multicolumn{3}{|c|}{$\begin{array}{l}\text { Turfgrass green-up (\%) } \\
\text { (inverse transformed values) }\end{array}$} \\
\hline & & & Mean & Lower 95\% CI & Upper 95\% CI \\
\hline 0 & aFIRST & $0.639(0.276)$ & 65.457 & 52.031 & 76.801 \\
\hline 0 & aSECOND & $-0.000(0.271)$ & 49.997 & 36.620 & 63.374 \\
\hline 0 & aTHIRD & $0.334(0.290)$ & 58.264 & 43.689 & 71.526 \\
\hline 61 & aFIRST & $0.505(0.202)$ & 62.370 & 52.407 & 71.385 \\
\hline 61 & aSECOND & $-0.874(0.196)$ & 29.435 & 21.922 & 38.260 \\
\hline 61 & aTHIRD & $0.588(0.222)$ & 64.289 & 53.485 & 73.813 \\
\hline 91 & aFIRST & $0.439(0.183)$ & 60.811 & 51.721 & 69.209 \\
\hline 91 & aSECOND & $-1.304(0.176)$ & 21.344 & 15.971 & 27.924 \\
\hline 91 & aTHIRD & $0.713(0.204)$ & 67.107 & 57.429 & 75.522 \\
\hline 157 & aFIRST & $0.294(0.202)$ & 57.309 & 47.160 & 66.878 \\
\hline 157 & aSECOND & $-2.250(0.195)$ & 09.533 & 6.628 & 13.527 \\
\hline 157 & aTHIRD & $0.988(0.221)$ & 72.873 & 63.193 & 80.781 \\
\hline 237 & aFIRST & $0.119(0.304)$ & 52.967 & 37.859 & 67.550 \\
\hline 237 & aSECOND & $-3.397(0.299)$ & 3.240 & 1.794 & 5.781 \\
\hline 237 & aTHIRD & $1.322(0.317)$ & 78.946 & 66.383 & 87.685 \\
\hline
\end{tabular}

LPG, liquefied petroleum gas; SE, standard error; CI, confidence interval; aFIRST, 14 days after the first flaming; aSECOND, 7 days after the second flaming; aTHIRD, 21 days after the third flaming.

flaming was evident, and the percentage of turfgrass green-up was reduced by all the LPG doses used, with a higher reduction when the dose was increased. This injury was recovered three weeks after the third flaming. It can be hypothesized that recover may have a different speed in different periods of the season. However, only one week is not sufficient to allow the turfgrass to recover from the injury caused by flaming.

Seashore paspalum is also sensitive to herbicides applications. Ethofumesate, flumioxanin, and sulfonylureas cannot be applied during the spring green-up (Yu et al., 2015). In our experiment conducted during the spring green-up, instead, the turfgrass showed a quite good recovery capacity after the flaming application, also when the highest dose was used. Yu et al. (2015) tested the herbicide amicarbazone which, compared to other damaging herbicides, appeared to be safe for seashore paspalum during dormancy, spring transition, and active summer growth. However, amicarbazone inhibited the shoot growth of seashore paspalum for up to one month after treatment. Flaming inhibited the seashore paspalum growth for a maximum of one week. Data from this experiment showed that the recovery from flaming was faster compared to the use of amicarbazone. Plant recovery after flaming is greatly dependent on the plant's ability to regrow. The annual broadleaf generally desiccates completely a few days after flaming, whereas grassy species generate new leaves after a few weeks (Ulloa et al., 2010).

Three weeks after the third flaming (31 May), the green-up was again statistically similar in the weedy control and when all the LPG doses used, but the benefit of flaming was that in the plots were the highest doses were used (157 and $237 \mathrm{~kg} \mathrm{ha}^{-1}$ ) both weed cover and weed density were significantly lower compared to the control and lowest doses. This suggests that at lowest doses (61 and $91 \mathrm{~kg} \mathrm{ha}^{-1}$ ), the high weed competition led to a green-up similar to that estimated in the control. At highest doses (157 and 237 $\mathrm{kg} \mathrm{ha}^{-1}$ ) the green-up was not higher compared to the control, even if weeds were statistically lower, probably because of injury caused by flaming, which had still not recovered three weeks after the treatment. However, the aim of obtain a turfgrass with a little presence of weeds was attained with higher LPG doses.

\section{Conclusions}

Flaming can be used for selective weed control during the spring green-up of seashore paspalum. The lowest LPG doses used (i.e. 61 and $91 \mathrm{~kg} \mathrm{ha}^{-1}$ ) were the most economic, but led to an insufficient level of weed control. The LPG dose of $157 \mathrm{~kg} \mathrm{ha}^{-1}$ led to a significant reduction in initial weed cover and density, and compared with the dose of $237 \mathrm{~kg} \mathrm{ha}^{-1}$ had a lower cost per use. The turfgrass recovered from the injury caused by flaming, as shown by the percentage of green-up that increased three weeks after the third treatment. The experiment was based on a single experiment, carried out once in a single location, therefore it deserves to be repeated over time to confirm these results. Flaming does not imply the presence of residues in soil and/or water, as in the case of herbicides. Given that tolerance to flaming may vary from species to species, further studies on other turfgrass warmseason species are needed in order to investigate the use of selective flame weeding as an alternative to chemical herbicides.

\section{References}

Abu-Dieyeh M., Watson A. 2005. Impact of mowing and weed control on broadleaf weed population dynamics in turf. J. Plant Interact. 1:239-52.

Bates D., Maechler M., Bolker B., Walker S. 2015. Fitting linear mixed-effects models using lme4. J. Stat. Softw. 67:1-48.

Brede D. 2000. Turfgrass maintenance reduction handbook: Sports, lawns, and golf. Sleeping Bear Press, Chelsea, MI, USA.

Busey P. 2003. Cultural management of weeds in turfgrass: A review. Crop Sci. 43:1899-911.

Cisar J.L. 2004. Managing turf sustainably. New directions for a diverse planet. In Proc. 4th Int. Crop Sci. Congr. Brisbane, Australia.

Croce P., De Luca A., Mocioni M., Volterrani M., Beard JB. 2001. Warm-season turfgrass species and cultivar characterisations 
for a Mediterranean climate. Int. Turfgrass Soc. Res. J. 9:3-7.

Diesburg K.L., Christians N.E., Moore R., Branham B., Danneberger T.K., Reicher Z.J., Voigt T., Minner D.D., Newman R. 1997. Species for low-input sustainable turf in the U.S. Upper Midwest. Agron. J., 89:690-4.

Duncan R.R., Carrow R.N. 2000. Seashore Paspalum - The environmental turfgrass. John Wiley \& Sons, Hoboken, New Jersey.

European Commission. 2009. Directive 2009/128/EC of the European Parliament and of the Council of 21 October, establishing a framework for Community action to achieve the sustainable use of pesticides. O.J. Eur. Union, 71-86. L 309 24/11/2009.

Fontanelli M., Frasconi C., Raffaelli M., Martelloni L., Abou Chehade L., Peruzzi A. 2017. Can flaming be performed as selective weed control treatment in turfgrass? Chem. Eng. Trans. 58:241-6.

Fox J. 2003. Effect displays in R for generalised linear models. J. Stat. Softw. 8:1-27.

Frasconi C., Martelloni L., Fontanelli M., Raffaelli M., Marzialetti P., Peruzzi A. 2017. Thermal weed control in photinia x fraseri "red robin" container nurseries. Appl. Eng. Agric. 33:345-56.

Gaetani M., Volterrani M., Magni S., Caturegli L., Minelli A., Leto C., La Bella S., Tuttolomondo T., Virga G., Grossi N. 2017. Seashore paspalum in the Mediterranean transition zone: phenotypic traits of twelve accessions during and after establishment. Ital. J. Agron. 12:110-5.

Hunt D. 2001. Chapter 4: Costs. pp. 75-77 in Farm Power and Machinery Management. Waveland Press, Long Grave, IL, USA.

Knezevic A. 2008. Overlapping confidence intervals and statistical significance. Available from: https://www.cscu.cornell.edu/news/statnews/stnews73.pdf Accessed: October 2018.

Kuznetsova A., Brockhoff P.B., Christensen RHB. 2016. lmerTest: tests in linear mixed effects models. R package version 2.0-32. Available from: https://CRAN.Rproject.org/package=lmerTest Accessed: October 2018.

Martelloni L., Fontanelli M., Frasconi C., Raffaelli M., Peruzzi A. 2016. Cross-flaming application for intra-row weed control in maize. Appl. Eng. Agric. 32:569-78.

Martelloni L., Fontanelli M., Frasconi C., Raffaelli M., Pirchio M., Peruzzi A. 2017. A combined flamer-cultivator for weed control during the harvesting season of asparagus green spears. Span. J. Agric. Res. 15:e0203.

Peruzzi A., Martelloni L., Frasconi C., Fontanelli M., Pirchio M., Raffaelli M. 2017. Machines for non-chemical intra-row weed control in narrow and wide-row crops: a review. J. Agric. Eng. 48:57-70.

R Core Team, 2016. R: A language and environment for statistical computing. R Foundation for Statistical Computing, Vienna, Austria. Available from: https://www.R-project.org/ Accessed: October 2018.

Raffaelli M, Frasconi C, Fontanelli M, Martelloni L, Peruzzi A, 2015. LPG burners for weed control. Appl. Eng. Agric. 31:717-731.

Raffaelli M., Martelloni L., Frasconi C., Fontanelli M., Peruzzi A. 2013. Development of machines for flaming weed control on hard surfaces. Appl. Eng. Agric. 29:663-73.

Reed T.V., McCullough P.E. 2014. Tolerance of five warm-season turfgrass species to flumioxazin. Weed Technol. 28:340-50.

Robbins P., Birkenholtz T. 2003. Turfgrass revolution: measuring the expansion of the American lawn. Land Use Pol. 20:181-94.

Smith J., Wherley B., Reynolds C., White R., Senseman S., Falk S. 2015. Weed control spectrum and turfgrass tolerance to bioherbicide Phoma macrostoma. Int. J. Pest Manage. 61:91-8.

Trenholm L.E., Carrow R.N., Duncan R.R. 2000. Mechanisms of wear tolerance in seashore paspalum and bermudagrass. Crop Sci. 40:1350-7.

Ulloa S.M., Datta A., Knezevic S.Z. 2010. Tolerance of selected weed species to broadcast flaming at different growth stages. Crop Prot. 29:1381-8.

Wickham H. 2009. ggplot2: Elegant Graphics for Data Analysis. Springer-Verlag, New York, NY, USA.

Yu J., McCullough P.E., Czarnota M.A. 2015. Seashore paspalum tolerance to amicarbazone at various seasonal application timings. Weed Technol. 29:42-7.

Żurek G., Tomaszewski B. 2009. Low maintenance turf - quality and low aspects. Plant Breed. Seed Sci. 59:13-20. 